\title{
The Light and Shadow Brought to Teacher Education by Digitizing the Educational Environment: The Case of Japan
}

\author{
Toshiyuki Kihara
}

check for updates

Citation: Kihara, T. The Light and Shadow Brought to Teacher Education by Digitizing the Educational Environment: The Case of Japan. Educ. Sci. 2021, 11, 399. https://doi.org/10.3390/ educsci11080399

Academic Editor: Eleanor Dommett

Received: 7 June 2021

Accepted: 29 July 2021

Published: 3 August 2021

Publisher's Note: MDPI stays neutral with regard to jurisdictional claims in published maps and institutional affiliations.

Copyright: (C) 2021 by the author. Licensee MDPI, Basel, Switzerland. This article is an open access article distributed under the terms and conditions of the Creative Commons Attribution (CC BY) license (https:// creativecommons.org/licenses/by/ $4.0 /)$.
The United Graduate School of Professional Teacher Education, Osaka Kyoiku University, Osaka 5430054, Japan; tkihara@cc.osaka-kyoiku.ac.jp

\begin{abstract}
In this paper, the trends and issues of teacher education research and practices in Japan are clarified from the viewpoint of the digitization of the educational environment. This will be achieved through a review of the literature and policy documents on recent educational practices and teacher education. Firstly, Japanese teacher education and the ICT environment in schools are summarized. In addition, the Japanese concept of "teachers who continue to learn" and its multidimensional character is explained. Secondly, a model of the above idea that consists of five dimensions is introduced: (1) social navigators, (2) technical experts, (3) inquiry practitioners, (4) critical practitioners, and (5) members of professional learning communities. Thirdly, through the review, it is pointed out that all of them are affected by the digitization of the educational environment, which has been accelerated as a countermeasure to COVID-19. In conclusion, it is stated that the digitization of the educational environment and its accelerated progress casts both light and shadow on the role of Japanese teachers as reflective practitioners. Additionally, it is referenced that there are many differences among schools and regions on the ratio of light and shadow in Japan, even though it is geographically small.
\end{abstract}

Keywords: teacher image; teacher development; teacher education; professional learning community; lesson study; educational environment; Japan

\section{Japanese Teacher Training and the Digitization of the Educational Environment in Japan}

In this paper, literature and policy documents on recent educational practices and teacher education in Japan are referred to and the changes in teaching in Japan, due to the digitization of the educational environment, are clarified. This digitization has progressed dramatically, due to the COVID-19 pandemic that began in 2020. Therefore, in order to refer to the digitization of the educational environment in Japanese schools, it is essential to analyze the impact of COVID-19 on schools and teachers. Thus, in this paper, the digitization of the educational environment and the changes in schools and teachers during the COVID-19 pandemic are discussed comprehensively. Japan is one of the countries where the digital industry has developed, and people all over the world often use the digital devices of Japanese companies. However, until a few years ago, digital devices were not fully equipped in Japanese schools. Therefore, the use of digital devices was unpopular in Japanese school classes. Digital devices were rapidly prepared in Japanese schools as a countermeasure against the COVID-19 pandemic. Through literature research and private communication, we confirmed that such hasty digitization brought about complex situations that teachers could not solve, disparities among schools and regions, and so on. That finding seems to be a consideration for the progress of digitization of school education in other parts of the world.

At first, the framework of the Japanese education system for future teachers and in-service teachers is confirmed and the current state of the digitalization of the educational environment is summarized for the readers. 


\subsection{Japanese Teacher Training and In-Service Education System}

In Japan, there are about 20,000 elementary schools (6 years), about 10,000 junior high schools ( 3 years), and fewer than 5000 high schools ( 3 years), including national, public, and private schools. [1] There are about 12,600,000 children studying at these schools and about 900,000 teachers working at them.

To become a regular teacher at a Japanese school, one must have a teacher's license. The conditions for obtaining a teacher's license are stipulated by the "Education Personnel License Law". Although it is possible to meet the conditions through various routes, in many cases, aspiring teachers obtain credits stipulated by the Teacher's License Law at universities and obtain a license from the board of education in their region. The credits required to obtain a license include those from practical training. However, the period is shorter than in other countries. For example, in the case of elementary schoolteachers, only four weeks are required. In junior high school, it shrinks to three weeks. Therefore, many universities that are engaged in teacher training have their own field experience at schools in order to give students who want to become teachers hands-on experience beyond the number of credits stipulated by the Education Personnel Certification Act. However, there are disagreements about the merits and demerits of this [2].

Students who wish to become teachers are required to take and pass the teacher employment examination, held by the board of education, in order to become a teacher at a public school after obtaining a license. After that, they will be listed on the faculty list. In addition, once every 10 years, in order to maintain their license, schoolteachers must take a license renewal course conducted by a university and be certified for completion.

Training for public schoolteachers is planned and managed by the board of education that manages the school in which the teachers work. There are several types. First, there is training for in-service teachers whose framework is stipulated by the "Special Law for Educational Public Employees". Teachers receive novice training as soon as they are hired. It must consist of $300 \mathrm{~h}$ or more of training instructed and supported by the principal or mentor at the school and 25 days or more of training outside the school, such as at an education center. Training is required by the above-mentioned laws and regulations, even for teachers who have about 10 years of teaching experience. It is called "Training for improving the qualifications of mid-career teachers". They will spend about 20 days on it.

Although not required by law, each board of education plans and manages various trainings, other than the above two. For example, there is training according to job title. Boards of education provide training for teachers in positions, such as school principals and curriculum coordinators. Alternatively, they also conduct task-specific training, for example, training regarding what kind of curriculum and instruction should be needed under the digitization of the educational environment, which is dealt with in this paper; the boards of education appoint leader teachers who are in a position to respond to such educational issues at schools.

In Japan, due to the revision of the Special Law for Educational Public Employees in 2017, the boards of education had to set a "teacher training indicator" that shows the criteria for what teachers aim for and how to learn; it is obligatory to create this. Based on that, it became necessary to plan and manage teacher recruitment and training. In addition, it became necessary to organize a "teacher training council", which is an organization to strengthen cooperation with the universities involved in teacher training. However, the function of teacher training indicators in Japan is different from that of teacher standards in other countries. For example, so far, teacher development indicators have not been directly applied to teacher recruitment and evaluation. They are positioned as a material for dialogue between universities and the boards of education, as well as between principals and teachers.

In Japanese elementary, junior high, and high schools, school-based training (in-school training) centered on the so-called lesson study has been active for more than 100 years. Lesson study is an activity in which teachers collaborate with colleagues to plan and implement research lessons, as well as to discuss the results and issues with them. It is 
operated under various methodologies [3] but is a common activity that combines lesson improvement and curriculum development with teacher competence formation. In the case of Japan, it is linked to activities, such as holding practical research conferences that open classes to teachers at other schools and creating documents that describe research practices. Lesson studies and related activities are modeled, as shown in Figure 1 [4]. In other words, in Japanese schools, lesson study is a multifaceted activity based on a research theme set by the school. In addition, an annual plan has been formulated that defines the timing and number of lesson studies, the person in charge of conducting the research lessons, etc., so that the content of the research lesson (and the discussions related to it) will continue and develop. In addition, some schools put the practice into document form (such as a portfolio) and have it evaluated by a third party. However, there are differences in the degree of fulfillment between elementary, junior high, and high schools [5].

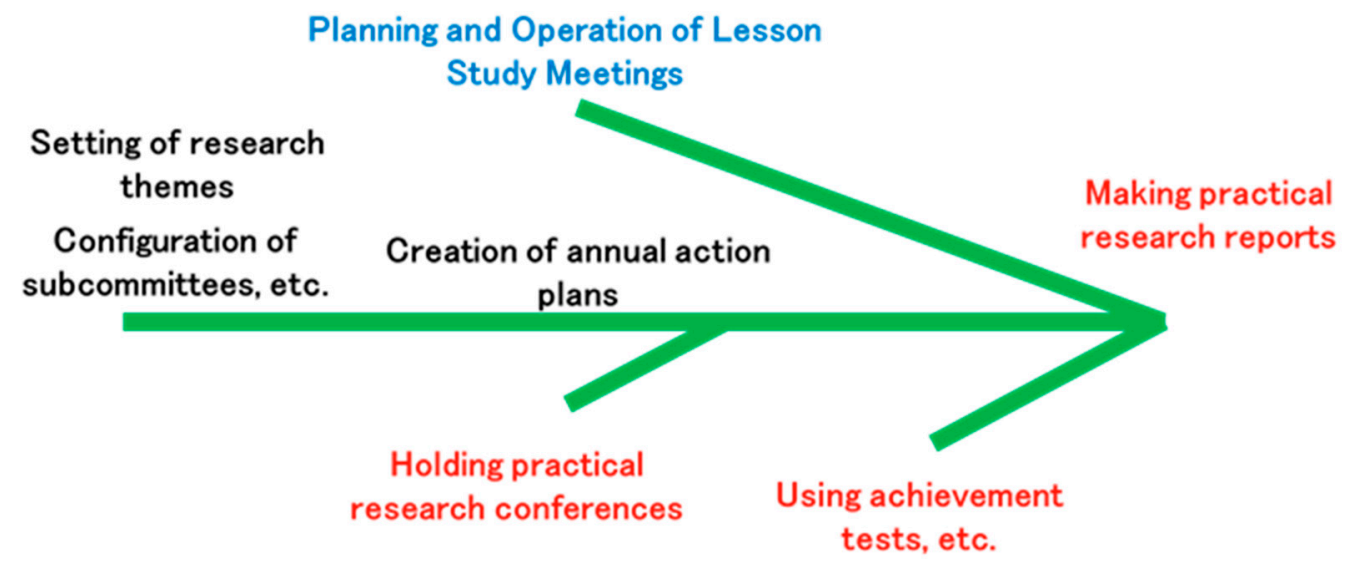

Figure 1. Lesson study as a core activities of school-based action research ([4], p. 371).

Furthermore, Japanese teachers have a culture of learning from each other voluntarily during off-hours. This has been called "circle activity." For example, once a month, some teachers meet at another school to discuss how to improve their subject teaching methods. They also document and share their practices. Alternatively, if a public interest incorporated foundation or university holds a seminar on ICT utilization on a Saturday, dozens of teachers will gather at it. In addition, some teachers take leave to study at a graduate school.

\subsection{Current Status of the Digitization of the Educational Environment in Japan}

Japan has a thriving digital industry. Around the world, people see digital products made in Japan. However, the ICT environment of Japanese schools is vulnerable. For example, according to the results of the March 2020 "Survey on the actual situation of computerization of education in schools" conducted by the Ministry of Education, Culture, Sports, Science and Technology (MEXT) at elementary, junior high, and high schools in Japan, 1 computer is shared by 4.9 children. In other words, on average, only 100 computers were deployed in a school with 490 children [6]. This number was 7.0 in March 2008. Since then, the figures have been decreasing year by year; the ICT environment was improved to some extent by March 2020, although it was not sufficient. However, as will be described later, the ICT environment was rapidly improved in response to COVID-19; in 2021-2022, many schools will establish a one-to-one computer-student ratio.

Therefore, before 2020, children had limited opportunities to use ICT in Japanese school classes. This is clear from the results of an international comparative survey. For example, the survey "International comparison of time spent in classroom lessons in a week", conducted by the OECD, asked, "How much do you use digital devices in classroom lessons in your usual week?" On average, $48.2 \%$ answered that they would not use language classes, but in Japan it was as high as $83.0 \%$ [7]. Regarding mathematics and science, the number of respondents who responded "do not use" was much higher than the OECD average. In addition, the rate of using computers for study at home is also the lowest 
among the OECD countries. On the other hand, the proportion of children who engage in online chat and games daily, or almost daily, is much higher than the OECD average. In other words, children use the digital environment outside of school and for purposes other than learning; their experience is largely unconnected to school use.

In order to bridge this gap, in Japan, a budget for the so-called "GIGA School Concept" was included in the supplementary budget for the same year, which was approved by the cabinet in December 2019. According to a leaflet created by MEXT, this is a concept with the following contents:

- By integrally developing a one-to-one computing environment with a high-speed, large-capacity communication network, an educational ICT environment will be realized that is fairly individually optimized for any diverse children, including children who need special support, to be cultivated more reliably.

- The power of teachers and students will be maximized by creating the best mix of Japanese traditional educational practices and cutting-edge ICT.

In Japan, it is the responsibility of the boards of education to improve the educational environment of schools. However, this did not necessarily progress nationwide until COVID-19. In order to overcome this situation, MEXT has pushed the above-mentioned GIGA School Concept. As a result, most of the above-mentioned costs for improving the ICT environment were subsidized by the government.

As will be described later, from April to May 2020, Japanese elementary, junior high, and high schools nationwide were closed to prevent the spread of COVID-19. Therefore, MEXT urged the boards of education to move ahead with the GIGA School Concept, which was originally planned to be developed over three years, and many boards of education responded. In March 2021, MEXT published a document entitled "Progress of the ICT environment improvement toward the realization of the GIGA School Concept (preliminary figures)" [8]. This is a report of the results of a survey of boards of education nationwide. According to the report, "1769 local governments (97.6\%) out of all local governments are expected to complete delivery by the end of FY2020". Regarding the network environment, " $86.2 \%$ of schools will start operation by the end of 2020 , and $97.9 \%$ of schools will start operation in April 2021."

As mentioned above, the educational environment of elementary, junior high, and high schools in Japan is being rapidly digitized. Therefore, in initial teacher training, each university prepares a course for aspiring teachers to acquire the ability to use the ICT equipment in school lessons, and all aspiring teachers will acquire the related skills. In addition, for in-service education, the boards of education actively plan and manage training for leader teachers and managers at each school.

\section{The Image of Teachers Expected in Japan Today: Teachers Who Develop Multidimensional and Sustainable Reflections}

In Japan today, continuing to learn is regarded as important for teachers. From the author's point of view, this should be a multidimensional activity. In other words, it is defined (by the author) as the image of today's Japanese teachers: teachers who carry out multidimensional and sustainable reflections. Based on the findings of various studies on teacher development involved in modern school education [9-33], this can be reduced inductively to about five teacher profiles (Figure 2). This indicates five types of profiles, according to the framework of reflection. First, the contents of reflection differ between 1 and 2-5 (the former is general and the latter specialized). In addition, in 2 to 4 and 5, there is a difference between an individual and a group in the subject of reflection. In $2-4$, the subject of reflection expands from the micro to the macro. 


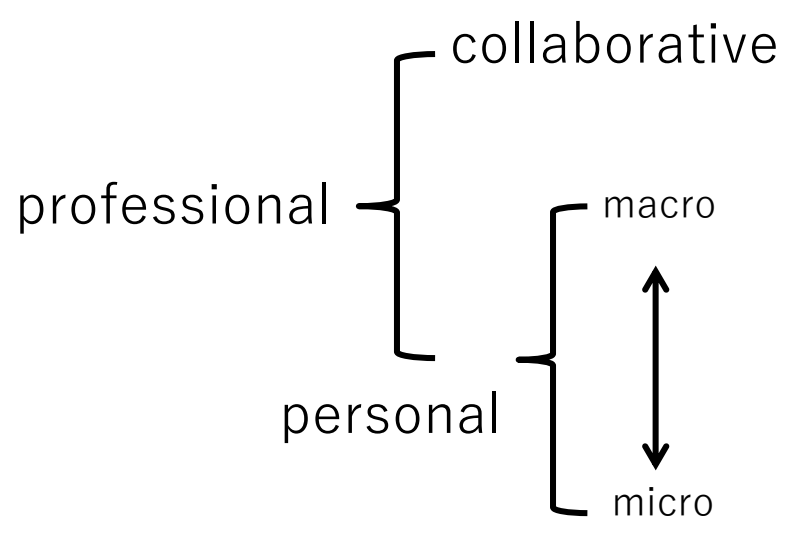

general

\begin{tabular}{|c|c|}
\hline Teacher profile & Typical ideas \\
\hline \multirow{3}{*}{$\begin{array}{l}\text { 5. members of } \\
\text { professional learning } \\
\text { community }\end{array}$} & collegiality \\
\hline & leadership \\
\hline & partnership \\
\hline \multirow{3}{*}{$\begin{array}{l}\text { 4. critical } \\
\text { practitioners }\end{array}$} & identity \\
\hline & commitment \\
\hline & resilience \\
\hline \multirow[b]{2}{*}{$\begin{array}{l}\text { 3. inquiry } \\
\text { practitioners }\end{array}$} & $\begin{array}{l}\text { practical knowledge } \\
\text { \& thinking }\end{array}$ \\
\hline & $\begin{array}{l}\text { ability to } \\
\text { accommodate the } \\
\text { diversity of children }\end{array}$ \\
\hline \multirow[t]{2}{*}{ 2. technical experts } & $\begin{array}{l}\text { pedagogical content } \\
\text { knowledge }\end{array}$ \\
\hline & teaching skill \\
\hline \multirow{3}{*}{ 1. social navigators } & citizenship \\
\hline & 21 century skills \\
\hline & well-being \\
\hline
\end{tabular}

Figure 2. Five profiles of the teacher image in a changing society.

\subsection{Teachers as Social Navigators}

First, is the aspect "1. social navigators", which is positioned as the basis of the image of a teacher who develops reflections in a multidimensional and sustainable manner. It consists of three sub-items: well-being, twenty-first century skills, and citizenship. They are not abilities and qualities peculiar to the teaching profession. They are the abilities and qualities required of active human resources who work in a twenty-first century society, from the viewpoint of the "Learning Compass" by OECD [9].

Well-being means that people can reach their potential, work constructively and creatively, have strong bonds with others, and contribute to the community [10]. In order for individuals to engage in, and continue, their constructive and collaborative activities in society, they must feel happy in their lives and, therefore, be mentally stable. From this point of view, it is appropriate to place well-being as the basis of the "teachers who carry out multidimensional and sustainable reflections" proposed in this paper.

Next is a new skill, symbolized by twenty-first century skills. These consist of 10 skills (4 categories), according to the ATCS21 (21st Century Skills Learning and Evaluation) project [11]. They are (1) creativity and innovation; (2) critical thinking, problem solving, and decision-making; (3) learning to learn/meta-cognition (knowledge about cognitive processes) (above, way of thinking); (4) communication; (5) collaboration (teamwork) (above, way of working); (6) information literacy; (7) ICT literacy (above, tools for working); (8) citizenship; (9) life and career; and (10) personal and social responsibility, including cultural awareness and competence (above, ways of living in the world). From the breadth of the ability elements from (1) to (10), it is clear that twenty-first century skills are a concept composed of various elements. It should be noted that "creativity and innovation", of "ways of thinking", is positioned at the top of the 10 skills. In a research report entitled "Basic Principles of Curriculum Organization to Develop Qualities and Abilities to Respond to Social Changes", the National Institute for Educational Policy Research in Japan proposed "twenty-first century abilities" and how to develop them. In the same report, it was stated that a "twenty-first-century-type ability" has a three-layered structure, centered on the "thinking ability", the "basic ability" that supports it, and the "practical ability" that directs how to use it [12]. The fact that the two reports position thinking ability at the core of twenty-first century skills suggests that it may be positioned as the main pillar of the ability and qualities needed to be a social navigator.

A new "education" is needed. In a twenty-first century society, where globalism is advancing, for example, "citizenship" will be confirmed as something that people should 
have. For example, citizenship is a diverse component in the composition of citizenship in the UK national curriculum; it is referred to as "social moral responsibility", "community involvement", and "political literacy". Three pillars are emphasized [13]. As will be described later, as critical practitioners, teachers will analyze and consider the relationship between their own practices and politics; as social navigators, they will consider the relationship between themselves and the region, society, and politics.

\subsection{Teachers as Technical Experts}

A teacher, as a technical expert, has a lot of excellent knowledge and skills and is the profile of a teacher who can actually apply these to problem solving in the classroom.

The framework of the knowledge that teachers should have has gradually become clear in the reform of education in the United States, especially in the development of programs for improving the qualifications of teachers. For example, the following seven categories of teaching knowledge have been proposed as a draft for creating criteria that enable teacher assessment [14]:

- content knowledge

- general pedagogical knowledge

- curriculum knowledge

- pedagogical content knowledge

- knowledge of learners and their characteristics

- knowledge of educational contexts

- knowledge of educational ends, purposes, and values, as well as their philosophical and historical grounds

It is commonly understood that the fourth of the seven knowledge categories, "pedagogical content knowledge," is the most important one for teachers. Therefore, focusing on the complexity of knowledge, it has been pointed out that there is knowledge about the contents of teaching materials and students; knowledge about teaching methods and students; and knowledge about teaching materials, teaching methods, and students [15].

There is a long history of research on the technical framework that teachers should have [16], especially in the field of lesson study; the contents are organized according to the progress of the lesson. For example, it is thought that "when a lesson is regarded as a technical process carried out by a teacher, the whole is divided into a preparatory process including teaching material research and lesson design and an execution process" [17], p. 19. The lesson techniques are organized into (1) the study of teaching materials, (2) the design of lessons, and (3) the implementation of lessons. Furthermore, in the case of class implementation, four perspectives are prepared: (a) explanation, (b) questioning/answering, (c) instruction (organizing learning activities), and (d) evaluation.

\subsection{Teachers as Inquiry Practitioners}

A so-called "reflective practitioner" [18] may have a variety of objects on which to reflect [19]. However, the main pillar will be their own practice. In addition, as for development, there will be an activity to carry out reflection in collaboration with others.

For example, through an analysis of 11 lesson study cases (and relatively long-term ones), tools, concepts, and systems for "clinical teacher education" have been proposed [20]. "Tools" include participation observation, introspection recording, phenomenological analysis of records, lesson reflection, lesson assessment, card structuring, and storytelling. A "concept" is composed of experience, context, time spent, reciprocity, physicality, otherness, dialogue, and independence. The conditions that the system should have are teachers as researchers of educational practice, story, collaboration, place, differentiation = creation of deviation, reflection, private language, and a model.

A methodology of the lesson study for teachers to acquire practical knowledge has been proposed and practiced [21]. It is called the lesson reflection study and consists of (a) practice, (b) awareness of commitment, (c) initiation of reflection, (d) repetition of dialogue with data and self-reflection, (e) provisional setting of problems, and (f) repetition of the 
process of redesign. In addition, a higher education program has been developed that brings university students closer to such efforts, and the results and issues have been reported [22].

\subsection{Teachers as Critical Practitioners}

This is also the appearance of a teacher as a reflection practitioner, but the difference from the teacher profiles in Sections 2.2 and 2.3 is that the object of reflection is directed to macro-existence, such as politics and societies. In the past, reflective practices based on a critical approach have been adopted in American teacher education programs and in-action research by Western teachers. On the other hand, in Japan, there have been few except those by the teachers' union.

However, even in Japan today, the pressure on teachers from politics and society is greater than it was in the past. Schoolteachers in developed countries are required to plan and implement school reforms based on the results of academic achievement surveys. Since it is a relative evaluation, there will always be schools and regions where the survey results are unfavorable and problematic. The fire of such competition is fueled by the school selection system and the issue of school consolidation, and teachers are frustrated. In addition, problems such as financial distress in the home and poor morale in the community add to the difficulty of reform, which significantly exhausts teachers.

Even in such a situation, in order to achieve self-actualization, teachers are expected to have values (identities) that place the pursuit of an ideal teaching profession at the core of the ego. They also need a belief (commitment) to fulfill their responsibilities, based on the fact that the teaching profession is a socially precious activity, and an attitude (resilience) to endure and continue the failures inherent in the teaching profession.

The possession of such qualities and abilities by Japanese teachers will be a factor in improving children's academic ability. This has already been confirmed to some extent by research findings on teacher education in Western Europe. For example, a survey of 300 teachers from 100 schools in 7 regions of England revealed that teachers with greater commitment and resilience are more likely to improve their students' academic achievement than teachers who are not [23].

\subsection{Teachers as Members of Professional Learning Communities}

There is a certain history in the way of thinking that the growth and development of teachers is regarded as the process of participation in the community. For example, from the perspective of lifelong developmental psychology, teacher development is categorized and presented as four models [24], p. 38, and one of them is the "participation in the community" model. It is defined as "a model that attempts to describe how the members become full-fledged members in the community as a process of participation in the vocational community, and the process of interaction between the members from a sociocultural point of view". Today, community participation has come to be interpreted as being positioned in the concept of a "professional learning community", which is a characteristic activity of the teaching profession. The concept of a professional learning community is a concept of organizational growth that has emerged in the wake of the growing momentum to question the quality of academic achievement in the United States since the 1990s. This concept is based on research that revealed that teachers can share the wisdom they have accumulated through their own experiences if given the opportunity to explore and learn as a group [25]. The concept is also based on research on school curriculum reform, which found that it was effective and important to secure time for participatory decision-making involving all teachers and for collaborative teaching, rather than a top-down approach [26]. In support of this, in research on the teaching profession, attention was focused on the need to specialize the teaching profession, from the perspective of improving the quality of learning for students and the importance of teachers learning and cooperating in practice $[27,28]$.

Collegiality, which is the basis of a professional learning community, is created through communication and collaboration between members. However, it has become clear that 
there are various styles of collegiality among teachers. Some types of colleague relationships are formed to a very limited extent or pressed from outside the organization [29]. If so, the growth of teaching, as a profession, will not be sufficient. In order for teachers to build and maintain constructive and lasting collaborative relationships, it is important that they perceive collegiality in the sense of "community companions who share the prospects for learning and the process of their inquiry" [30], p. 257.

Activities in a professional learning community are planned and managed by "distributed leadership" based on the initiatives of multiple leaders. Therefore, managers, such as school principals and practical leaders (including curriculum coordinators and instructional leaders), are required to consider what role they should play in what situations. They need to engage in learning as leaders to acquire the more mature beliefs and complex practical knowledge required. Developmental research is underway to respond to this. For example, a handbook has been developed that provides self-study materials that allow leader teachers to acquire a diverse knowledge about "school-based curriculum development" from a professional standpoint [31]. This handbook consists of the theory and model of curriculum development, its practical trends, decision-making exercises (related to curriculum development), and reflections on the curriculum development of the school to which the user belongs.

Furthermore, recently, the importance of cooperation and collaboration among multiple professional learning communities has been pointed out and its possibilities have been theoretically and practically examined. The qualities and abilities to work positively, build joint relationships with partners, and expand practical knowledge will be indispensable for the organizational growth of schools today (partnership). Notable cases of inter-school cooperation in the Grand Erie district of Canada have been presented [32], including the joint-teacher training of multiple schools, called the Teaching and Learning Critical Pathway. This is an inter-school peer assessment system, in which teachers from multiple schools gather at centers and schools several times a year to exchange opinions on school reform. Despite the pressure of academic achievement surveys and the risk of fueling competition among schools, the functioning of these efforts is likely to contribute to the realization of school-based, academic achievement improvement approaches.

In Japan, the networking of professional learning communities actually has a certain history. Therefore, it can be said that its modernization is progressing in Japan. This can be represented, for example, by holding so-called practical research conferences. According to the history of practical research in Japanese schools, by the 1910s some schools held practical research conferences and opened their classes to the public. This was an "external evaluation" to clarify the results and issues of educational practice through the eyes of teachers from other schools, educational administration officials, parents and local residents, and university teachers [4].

There is a considerable history of activities by the boards of education, foundations, and companies planning and managing projects and in the process, multiple schools set common research themes that recirculate the wisdom of practice. In particular, in Japan's recent years, as part of measures to improve academic ability, many projects have been launched, in which the board of education asks each school to formulate an action plan and utilize the results of academic ability surveys. Because they use the same frameworks and tools, schools participating in such projects can easily build networks among professional learning communities.

Furthermore, inter-school cooperation for integrated education in elementary and junior high schools is also underway; its repertoire is wide [33]. Several times a year, teachers at elementary and junior high schools in a school district hold joint training. Another elementary and junior high schoolteacher is building a nine-year integrated curriculum. Furthermore, there are cases where teachers who are in charge of both elementary and junior high school classes are assigned. 


\section{Changes in the Image of Teachers}

The above profiles of teachers have had to change, due to the influence of the digitization of the educational environment, which has been accelerated as a countermeasure against the spread of COVID-19. Below, changes in the profiles of the image of teachers who develop multidimensional and sustainable reflections are explained.

Some information, that was the basis of the following statements, was obtained from the author's private conversations with the teachers at the school (where the author is the supervisor) and the graduate students of the professional school for teacher education (where the author works).

\subsection{Changes in the Profile of Teachers as Social Navigators}

Due to the spread of COVID-19, all schools in Japan were closed from April to May 2020 at the direction of the government. After that, if a person infected with COVID-19 was found (and there were many close contacts with children or teachers), the school took individual measures to close, according to the instructions of the local board of education. This was a big blow to Japanese teachers, who value direct communication with their students.

Even as the children came to school, the hardships of the teachers continued. For example, teachers had to instruct children not to talk to their friends as a measure to prevent infection during school lunches. This was due to a different guidance policy than before the spread of COVID-19. Not only the children, but also the teachers themselves (who are the instructors), were confused by the gap.

In other words, there were teachers who could not maintain their well-being, due to the loneliness caused by not being able to meet students at school and the frustration of not being able to communicate directly with them.

During the school closure, some Japanese schools started online classes. As of March 2020, the ICT environment in Japanese schools was not sufficiently developed. The GIGA School Concept has been pushed forward, and teachers have had to acquire the skills for online communication with their students. In other words, teachers were required to acquire skills corresponding to (6) information literacy and (7) ICT literacy of the twentyfirst century skills. This has made it inevitable that many teachers will acquire twenty-first century skills. However, as of April 2020, there were many cases where schools did not have network terminals for teachers and children, compared to companies. Therefore, during this period, Japanese teachers were embarrassed by the situation in which the development of the ICT environment (which is a prerequisite for acquiring information and literacy related to ICT) was not satisfied.

Unfortunately, in some schools, children and their parents became infected with COVID-19. In connection with this, teachers also had to teach other children. In other words, it was necessary to explain to children that everyone is at risk from COVID-19 and that the words and deeds that slander a child or their family should be strictly avoided. Since children often used SNS at home, there was concern that information about children infected with COVID-19 could be easily shared, which could cause bullying at school. Due to this, teachers reaffirmed the complexity of being citizens in a society where SNS is widespread.

\subsection{Changes in the Profile of Teachers as Technical Experts}

In Japan, COVID-19 has added the skill of teaching children online to the profile of teachers as technical experts. In Japan, teachers are required to introduce so-called active learning into their lessons, which has been fully implemented since 2020. Both teachers and advisory teachers of the boards of education have sought to find out how to carry out active learning online and what kind of teaching skills would be needed to do so. Schools in one area emphasized the ability of children to have small discussions using a video conferencing system. The children also wanted this but at the time, the teachers were worried about whether or not to join the group, and if so, which group to join. In the 
classroom, teachers can get a bird's-eye view of the children talking in small groups, but this is extremely difficult in online lessons. In response, some teachers instructed the children to write the content of the discussion in a cloud file, making the learning process of all groups accessible to both themselves and their students. However, few answers have been derived as to what teachers should do to facilitate learning among children in online lessons.

As a new educational content, information ethics that children must comply with when learning using cloud services are rapidly emerging. Even before the COVID-19 pandemic, Japanese teachers had been trying to foster an attitude of participation in the information society by covering information ethics and personal information protection at school. However, there are no subjects, such as information and computing in the curriculum of Japanese elementary and junior high schools (that is, schools at the stage of compulsory education). Therefore, there was a difference between teachers and schools in fostering attitudes toward participating in the information society. Then, during COVID-19, there was a problem where some children became more dependent on SNS and Internet games, especially during the school holidays. To prevent this, teachers had to hurry and design and implement lessons and curriculums that fostered an attitude of participation in the information society.

\subsection{Changes in the Profile of Teachers as Inquiry Practitioners}

Lesson study, which forms the core of this model, is based on observations of a research lesson. However, the spread of COVID-19 made this difficult. Many teachers were unable to enter the classroom while maintaining social distance. Therefore, some teachers were permitted to enter the classroom where the research lesson was being held, but others were forced to observe it from the corridor next to the classroom (Figure 3). In some schools, teachers acting as photographers entered the classroom and distributed the classes to teachers in other spaces over the network. The same applies to the discussion after the research lesson. The teachers were divided into several classrooms and used a video conferencing system to exchange opinions on the research lesson (Figure 4).

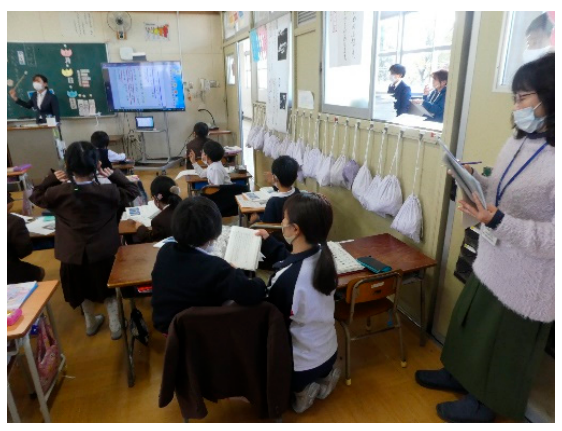

Figure 3. Teachers observing classes from the corrido.

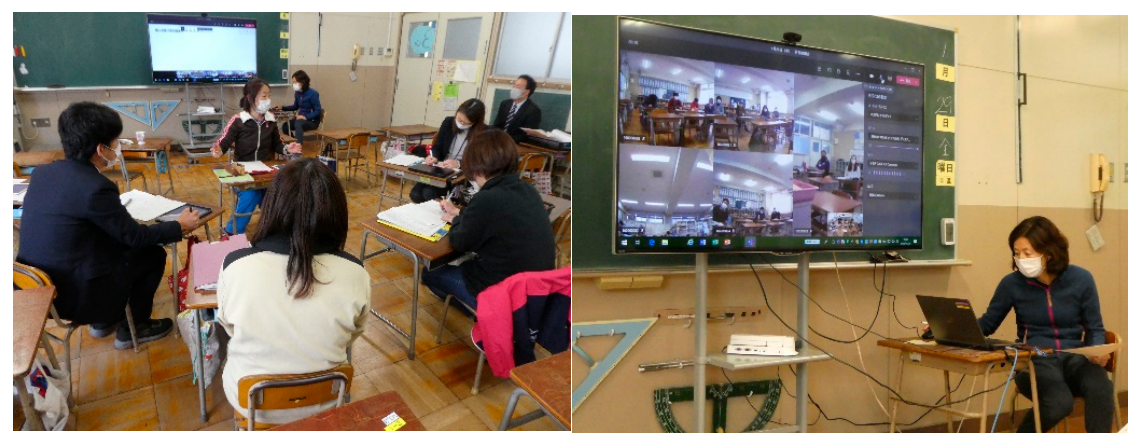

Figure 4. Exchange of opinions with colleagues in other classrooms using the video conferencing system. 
In Japan, even in the past, due to time constraints, one teacher's research lesson was shot with a video camera and the video recording was viewed by other teachers in their spare time. After school everyone discussed the research lesson. Some teachers performed similar activities outside of working hours, elsewhere, with teachers from other schools. In the lesson study, which is carried out as a "circle activity" introduced in Section 1.1., such a style was rather the basic type. However, until now, the problem remained that the records of the lessons were only part of the classroom landscape, and teachers had to discuss based on partial information about the research lessons. At the beginning of 2020, it was the same even in the case of synchronous distribution via the video conferencing system described above. However, in order to solve this problem, attempts have been made to shoot and distribute lessons using 360-degree cameras. Already, at the university level, some efforts were reported before the COVID-19 pandemic. For example, an all-sky lesson observation system that records collaborative learning by initial teacher training students has been prototyped, and the usefulness of the system has been evaluated [34]. It is also possible for a 360-degree camera to be used to photograph both the teacher and students at the same time; that is, the viewer can see the teacher's teaching method and the students' reaction at the same time [35].

Since June 2020, teachers at elementary, junior high, and high schools have also started to shoot research lessons in progress with a 360-degree camera and distribute the video recordings. This has increased the possibility that teachers who observe research lessons will be able to view them actively and from multiple perspectives.

It is expected that there will soon be cases where the research lesson itself is conducted in an online format. Of course, there is currently no consensus on whether a situation where teachers in the classroom use video conferencing systems to teach children at home can be considered a formal "class." However, if the lockdown situation due to COVID-19 continues for a long time, the idea of what kind of lessons can be established will be expanded (even in Japan), where the need for distance education is not so high. In this way, online research lessons may be expanded.

The problems of lesson study, which is being promoted by digitization and online classes, cannot be overlooked. With that in mind, an organization called Lesson Study UK has already created and published guidelines on lesson studies for online lessons [36].

\subsection{Changes in the Profile of Teachers as Critical Practitioners}

During the COVID-19 pandemic, the profile of a teacher as a critical practitioner has arisen. This is partly because MEXT presented the 2020 "Comprehensive Measures Package for Children's 'Learning Guarantee' with COVID-19 Infectious Disease Control.” It calls for (1) clarification of the concept of learning guidance for effective learning security, and (2) human and physical support necessary for learning security for the entire country [37]. The idea used in this document, "By all means, to maximize learning without leaving any children behind," is universal. Then, MEXT and the boards of education showed the teachers a policy for providing concrete support for that purpose. Therefore, teachers had difficulty turning critical thinking toward educational administration. The devastation of COVID-19 arrived with little warning and society changed suddenly, so it can be said that there was no mental leeway to grasp education from a macro perspective.

MEXT has set up a special "Children's Learning Support Site" to collect learning support videos created by the boards of education and programs for NHK and the Open University of Japan [38]. In addition, some board of education supervisors conducted mock lessons themselves; they asked colleagues to shoot videos of them and used them as content for children's learning through networks, cable TV, and so on.

These support policies and measures by the educational administration have encouraged many Japanese teachers to maintain their identities and commitment and to demonstrate resilience.

However, using SNS, some teachers disclosed their critical views. For example, it was revealed that some teachers even disinfected the desks and chairs of all the children in 
the classroom since the school was reopened in mid-June 2020. Some lamented that the kits (for example, splash prevention boards) prepared by the school board for children to maintain social distance were not useful in the classroom.

\subsection{Changes in the Profile of Teachers as Members of a Professional Learning Community}

It can be said that the digital environment has promoted the diversification of the profile of teachers as members of a professional learning community. As mentioned earlier, the school-based lesson study traditionally practiced by Japanese teachers was suppressed during COVID-19 to maintain social distance, making it more likely that teachers would visit classes at other schools online and talk with research lesson teachers.

Figure 5 shows a high school music class being distributed to music teachers at other schools through a video conferencing system. Generally, in Japanese high schools, there are not many teachers who belong to the music department. Therefore, it is difficult to form a community within the school to learn about music lessons. Securing opportunities to exchange views on music lesson creation across schools has never been easier. This is because it was difficult for teachers to overcome the problems of having someone replace their lessons and taking time to move. With a digital environment that makes it relatively easy to do, teachers are promoting lesson studies across schools.

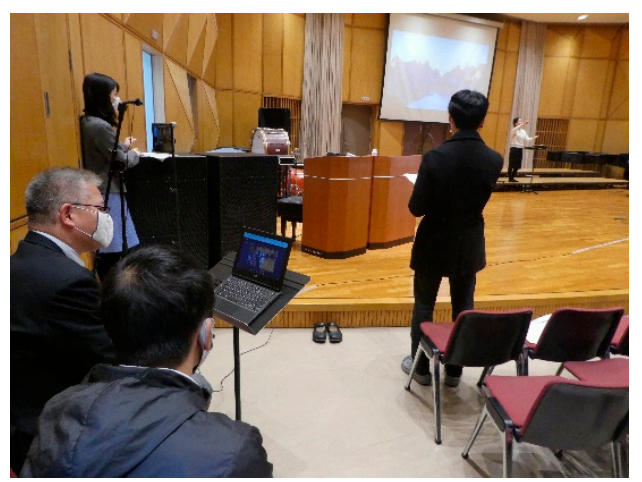

Figure 5. Delivery of research lessons to teachers at other schools using a video conferencing system.

This expansion of lesson study via ICT became apparent in the "holding of a practical research conference" seen in the model in Figure 1. In the past, teachers working at schools in geographically distant areas had to spend considerable time and energy to attend practical research conferences in another area. Holding online practical research conferences alleviated this problem. From June 2020 to February 2021, many practical research conferences using video conferencing systems were planned and held in Japan. Many teachers from remote schools participated in the conferences and built a lesson study network. In addition, some schools recorded the lessons and discussions of the day, published the video recordings on the school's website after the event, and accepted criticism. This entails the possibility of expanding the professional learning community over time.

It should be mentioned that in conducting online lessons, teachers also need to strengthen their collaboration with ICT support staff (who are experts in ICT technology). In other words, teachers must collaborate for their students' sake across occupations, even within the same school.

\section{Characteristics of the Impact of the Digitization of the Educational Environment on Teachers}

As mentioned above, the digitization of the educational environment in Japanese schools has progressed quickly, triggered by the COVID-19 pandemic. In the previous section, it is explained how the accelerated progress has affected the profiles of the image of teachers who develop multidimensional and sustainable reflection. Here, based on the 
description in the previous section, the impact of the rapid digitization of the educational environment on teacher education in Japan was summarized across three points.

\subsection{Effects of Both Light and Shadow}

COVID-19 and the digitization of the educational environment promoted by the educational administration brought both light and shadow to the image of teachers who develop multidimensional and sustainable reflection. For example, there was a change in the profile of teachers as "social navigators," as Japanese teachers lost the opportunity to communicate face-to-face with their students and guarantee their well-being. But in another sense, they had the opportunity (and were forced to) acquire twenty-first century skills, such as information literacy and ICT literacy.

Regarding the profile of teachers as "inquiry practitioners", the traditional lesson study style of directly observing children has become difficult to implement due to social distance rules during the spread of COVID-19. However, Japanese teachers have gained a lesson study approach that uses 360-degree cameras to perform multifaceted observations.

In Japanese schools, the author mentioned earlier, digitization had not progressed before COVID-19, so it is thought that both the light(merit) and the shadow(demerit) of the effect of the digital environment on the abilities of teachers were remarkable.

\subsection{Multi-Dimensionalization of Collegiality}

As mentioned in Section 4.1, COVID-19 (as a whole) and the digitization of the educational environment have brought light and shadow to teachers in Japanese schools. It seems that the profile of teachers as "members of a professional learning community" received a strong light. During the COVID-19 pandemic, from the beginning of 2020, it became difficult for Japanese teachers to have the opportunity to visit other schools. However, as mentioned in the previous section, they were able to observe classes at remote schools and communicate with many teachers by using a video conferencing system. As mentioned in Section 2.5, in Japan, the construction of inter-school networks has begun under various circumstances. The digitization of the educational environment has spurred this on. It has contributed to the multi-dimensionalization of collegiality among Japanese schoolteachers.

\subsection{Existence of a "Hard-to-See" Disparity}

The shadow of COVID-19 and the digitization of the educational environment relates to the aspect of teachers' profiles as "critical practitioners". As mentioned in the previous section, the educational administration has provided some support to schools. Additionally, COVID-19 brought teachers face-to-face with an emergency they did not foresee. This situation made it difficult for Japanese teachers to look critically at the political and social situation during the pandemic.

However, by nature, digitized learning should establish a good relationship with learning in which children communicate directly. Teachers should carefully consider the balance and combination of the two, as they are not in conflict. In other words, the harmony between traditional lessons and curriculums and its renewal should be better considered.

Moreover, in Japan, teachers are now encountering "hard-to-see" disparities related to the digitization of educational environments and are beginning to see them as problems. As confirmed in the Section 1, the COVID-19 pandemic triggered the realization of a oneto-one computing environment at most schools in Japan. In addition, the school network environment was generally improved. Nevertheless, some Japanese teachers are worried about the development and utilization of the ICT environment. It is a small but difficult problem that arises only in some schools and areas. For example, there were some cases where a one-to-one computing environment had been established, but the applications and digital textbooks could not be installed on each terminal. Some boards of education were unable to afford them. Additionally, some boards of education have been able to purchase 
them but have not been able to procure personnel and services to install them. In these cases, at school, teachers are surrounded by many terminals, but are at a loss.

Network environments are often a source of concern for teachers. As confirmed in the Section 1, the GIGA School Concept should have strengthened the school network environment. However, in general, some schools (such as schools with more than 1000 children) do not fully utilize the network. Since there are few schools of that size in Japan, it was difficult for the boards of education, which promoted the improvement of the ICT environment of schools, to predict the situation where many children would access the network at one time.

The idea of "not stopping children's learning" is precious. When it was connected to the digitization of the educational environment, Japanese teachers were less likely to exhibit a critical spirit toward the educational administration's approach. However, even in Japan, it will be necessary for teachers who are involved in the classroom to calmly assess the possibilities and issues of the digitization of the educational environment and reflect them in their educational practices.

\section{For Further Criticism}

Figure 2, which is the framework for producing the findings in this study, was created by the author collecting and classifying the literature that discusses the competence and development of teachers, as described in the Section 3. However, the fact that it was not necessarily a systematic review is the first problem in this paper.

The digitization of the educational environment is advancing day by day. However, it takes time for measures related to teacher education and practices in the classroom to be targeted and published as papers. Therefore, in the review of this paper, the references to the literature were not sufficient. In addition, the Section 3 narrative is based on the cases observed by the author, as well as the information obtained from some teachers and graduate students. Therefore, the results may be biased, and caution should be exercised in generalizing the findings. That is the second problem of this paper to be solved.

Looking at the statistical results of TALIS2018, the working styles of Japanese teachers are unique [39]. Therefore, it is necessary to consider whether the topic under consideration is a problem peculiar to Japanese schoolteachers or is somewhat universal. In other words, there is a need for international comparison.

Funding: Part of this research was funded by Japan Society for the Promotion of Science, Grant-in-Aid for Scientific Research (B), grant number 24300284.

Institutional Review Board Statement: Not applicable.

Informed Consent Statement: Not applicable.

Data Availability Statement: Not applicable.

Acknowledgments: The author would like to thank the many Japanese teachers who carefully taught me the state of school classes during the COVID-19 pandemic.

Conflicts of Interest: The author declares no conflict of interest.

\section{References}

1. "Basic Survey of Schools" at the Window of "Government Statistics" in Japan. Available online: https://www.e-stat.go.jp/statsearch $/$ files?page $=1 \&$ layout $=$ datalist\&toukei $=00400001 \&$ tstat $=000001011528 \&$ cycle $=0 \&$ tclass $1=000001148386 \&$ tclass $2=00000$ $1148404 \&$ tclass $3=000001148405 \& t c l a s s 4=000001148406 \& t c l a s s 5 \mathrm{val}=0$ (accessed on 16 May 2021). (In Japanese)

2. Mochizuki, K. Kyōiku jisshū to gakkō sanka taiken [Educational Training and School Participation Experience]. In Kyōshi Kyōiku Kenkyü Handobukku [Teacher Education and Research Handbook]; Nihon kyōshi kyōiku gakkai, Japan Society for Teacher Education, Ed.; Gakubunsha: Tokyo, Japan, 2017; pp. 242-245. (In Japanese)

3. Himeno, K. Recent Trends of Research on Classroom Instruction and Teacher Education Based on the Educational Technology Approach. Educ. Technol. Res. 2016, 39, 5-13.

4. Kihara, T. Lesson Study as a Core Activity of School-Based Action Researches. In Lesson Study in Japan; National Association for the Study of Educational Methods, Ed.; Keisuisha Co. Ltd.: Hiroshima, Japan, 2011; pp. 367-378. 
5. Chichibu, T.; Kihara, T. How Japanese schools build a professional learning community by lesson study. Int. J. Lesson Learn. Stud. 2012, 2, 12-25. [CrossRef]

6. Results of Survey on the Actual State of Informatization of Education in Schools in the First Year of Reiwa (Summary). Available online: https://www.mext.go.jp/content/20201026-mxt_jogai01-00009573_1.pdf (accessed on 15 May 2021).

7. National Institute for Educational Policy Research; Ministry of Education, Culture, Sports, Science and Technology. Key Features of OECD Programme for International Student Assessment 2018 (PISA 2018). 2019. Available online: https:/ / www.nier.go.jp/ kokusai/pisa/pdf/2018/01_point-eng.pdf (accessed on 16 May 2021).

8. Progress of ICT Environment Development for the Realization of the GIGA School Concept (preliminary Figures). Available online: https:/ / www.mext.go.jp/content/20210315-mxt_jogai01-000009827_001.pdf (accessed on 13 May 2021). (In Japanese)

9. The OECD Learning Compass 2030. Learning Compass 2030-OECD Future of Education and Skills 2030. Available online: https:/ / www.oecd.org/education/2030-project/teaching-and-learning/learning/learning-compass-2030/ (accessed on 4 July 2021).

10. Mental Capital and Wellbeing: Making the Most of Ourselves in the 21st Century. Available online: https:/ /assets.publishing service.gov.uk/government/uploads/system/uploads/attachment_data/file/292453/mental-capital-wellbeing-summary. pdf (accessed on 16 May 2021).

11. Griffin, P.; McGaw, B.; Care, E. (Eds.) Assessment and Teaching of 21st Century Skills; Springer: Dordrecht, The Netherlands, 2012.

12. The Project Research of the National Institute for Educational Policy Research in Japan. Basic Principles of Curriculum Organization to Develop Qualities and Abilities to Respond to Social Changes. 2013. Available online: https://www.nier.go.jp/05 _kenkyu_seika/pdf_seika/h25/2_10_all.pdf (accessed on 7 May 2021). (In Japanese)

13. Education for Citizenship and the Teaching of Democracy in the Schools: Final Report of the Advisory Group on Citizenship. Available online: https:/ / dera.ioe.ac.uk/4385/1/crickreport1998.pdf (accessed on 22 May 2021).

14. Shulman, L.S. Knowledge and Teaching: Foundation of the New Reform. Harv. Educ. Rev. 1987, 57, 1-22. [CrossRef]

15. Yoshizaki, S. Research on Teaching and Teacher Education (1)-Through the Mediation of Research on Teacher's Knowledge. Res. J. Educ. Methods Res. 1987, 13, 11-17. (In Japanese)

16. Sato, M. Kyōiku Hōhō-Gaku [Educational Methodology]; Iwanamishoten: Tokyo, Japan, 1996. (In Japanese)

17. Shibata, Y. Kyōiku Gijutsu No Tokushitsu wa Nani ka [What Are the Characteristics of Educational Technology?] In Kyōiku Jissen No Kenkyū [Study of Educational Practice]; Shibata, Y., Sugiyama, A., Mizukoshi, T., Yoshimoto, H., Eds.; Toshobunka: Tokyo, Japan, 1990; pp. 12-21. (In Japanese)

18. Schön, D. The Reflective Practitioner: How Professionals Think in Action; Basic Books Inc.: New York, NY, USA, 1983.

19. Kihara, T. Jugyō Kenkyū to Kyōshi No Seichō [Teacher Development Based on Classroom and Action Researches]; Nihonbunkyōshuppan: Osaka, Japan, 2004. (In Japanese)

20. Fujioka, K. The Clinical Education of Teachers and Its Tools. Jpn. J. Educ. Technol. 2003, 27, 49-59. (In Japanese)

21. Sawamoto, K. Jugyō rifurekushon o mochiita kyōiku jissen kenkyū[Educational Practice Research Using Class Reflection]. In Kyōiku Kōgaku ni Okeru Kyōiku Jissen Kenkyū [Educational Practice Research in Educational Technology]; Nishinosono, H., Ikuta, T., Oyanagi, W., Eds.; Minervashobo: Kyoto, Japan, 2012; pp. 30-49. (In Japanese)

22. Sawanoto, K. A Developmental Case Study of a University-level Course, 'Theory and Practice in Classroom Research', for Preservice Students: Self-Reflection on Classroom Research Supervision. Jpn. J. Educ. Technol. 2009, 32, 405-415. (In Japanese)

23. Day, C. Committed for life? Variations in teachers' work, lives and effectiveness. J. Educ. Chang. 2008, 9, 243-260. [CrossRef]

24. Akita, K. Kyōshi ga Hattatsu Suru Sujimichi [The Path of Teacher Development] In Jugyō de Seichō Suru Kyōshi [Teachers Growing Up in Teaching]; Fujioka, K., Sawamoto, K., Eds.; Gyousei: Tokyo, Japan, 1999; pp. 27-39.

25. McLaughlin, M.W.; Talbert, J.E. Teacher Professionalism in Local School Contexts. American, J. Educ. 1994, 102, $123-153$.

26. Darling-Hammond, L. The Quiet Revolution: Rethinking Teacher Development. Educ. Leadersh. 1996, 53, 4-10.

27. Rosenholtz, S.J. Teacher's Workplace; Longman: New York, NY, USA, 1989.

28. Hord, S.M. Professional Learning Communities: Communities of Continuous Inquiry and Improvement. Available online: https:/ / files.eric.ed.gov/fulltext/ED410659.pdf (accessed on 22 May 2021).

29. Hargreaves, A. Changing Teachers, Changing Times: Teachers' Work and Culture in the Postmodern Age; Cassell: London, UK, 1994.

30. Akita, K. Jissen no sōzō to dōryō kankei [Creation of Practice and Colleague Relationship]. In Kyōshi-zō No Sai Kōchiku [Reconstruction of Teacher Image]; Sato, M., Ed.; Iwanamishoten: Tokyo, Japan, 1998; pp. 235-259. (In Japanese)

31. Kihara, T.; Yano, H.; Mori, H.; Hirose, M. Development of the "Handbook for the Leading Teachers in Charge of School-Based Curriculum Development" from the Viewpoint of Curriculum Leadership. Jpn. J. Curric. Stu. 2013, 22, 1-14. (In Japanese)

32. Kihara, T.; Yano, H.; Mori, H. Development of a New Curriculum Leadership Model with a Focus on Its Relation to the Professional Learning Communities. In Back to the Future; Flores, M.A., Carvalho, A.A., Ferreira, F.I., Vilaca, M.T., Eds.; Sense Publishers: Rotterdam, The Netherlands, 2013; pp. 115-128.

33. Kihara, T. Kodomo no seichō hattatsu ni shisuru shōchū renkei [Collaboration between Elementary and Junior High schools that Contributes to the Growth and Development of Children]. Sch. Manag. 2009, 51, 12-15. (In Japanese)

34. Setozaki, N.; Tsurumoto, N.; Fujii, Y. Evaluation of the Spherical Panorama Classroom Observation System for Recording the Collaborative Learning. Bull. Fac. Educ. Nagasaki Univ. Comb. Issue 2017, 3, 191-198. (In Japanese)

35. Miyazaki, E.; Sakai, S.; Suginome, K.; Sakai, K.; Shimazaki, Y.; Kondo, H. Prototyping of the Trial Teaching System Using 360 Degree Camera. Mem. Fac. Educ. Kagawa Univ. 2019, 1, 15-20. (In Japanese) 
36. Online Research Lesson Study Do's and Don'ts. Available online: https://lessonstudy.co.uk/2021/02/new-free-to-downloadonline-research-lesson-study-dos-and-donts (accessed on 16 May 2021).

37. Guarantee of Learning Comprehensive Measures Package for Children and Students Associated with Measures against New Coronavirus Infectious Diseases. Available online: https://www.mext.go.jp/content/20200605-mxt_syoto01-000007688_1.pdf (accessed on 16 May 2021). (In Japanese)

38. Children's Learning Support Site. Available online: https://www.mext.go.jp/a_menu/ikusei/gakusyushien/index_00001.htm (accessed on 16 May 2021). (In Japanese)

39. TALIS 2018 Results (Volume I). Available online: https:/ / www.oecd.org/education/talis-2018-results-volume-i-1d0bc92a-en.htm (accessed on 21 May 2021). 